\title{
PENGHAMBATAN PERTUMBUHAN BATANG BAWAH KARET MELALUI METODE PEMANGKASAN TAJUK
}

\author{
Growth Inhibition of Rubber Rootstock Seedlings Through Shoot Pruning Method
}

\author{
JUNAIDI
}

Balai Penelitian Sungei Putih, Pusat Penelitian Karet

Galang, Deli Serdang, Po. Box 1415 Medan 2001

Email: junaidi.sp5@gmail.com

Diterima : 10 Maret 2020 / Disetujui : 2 April 2020

\begin{abstract}
The uncertain rubber planting material demand leads to the efforts of inhibiting the rootstock growth so that the lifetime can be extended. This study aimed to elucidate the effect of shoot pruning on the growth of rubber rootstock seedling. The study was arranged based on a Randomized Block Design (RBD) with three replications, each experimental unit used 10 polybags of plants. The pruning treatment consisted of three levels, i.e. $P O$ (control, without pruning), $P 1$ (two-stages pruning, above the first whorl (6 weeks after planting) and second leafwhorl (9 weeks after planting), and P2 (one-stage pruning above the first leaf whorl (6 weeks after planting)). The result showed that P1 treatment had a significantly lower stem diameter growth rate $(0.30 \mathrm{~mm} /$ week) compared to control $(0.38 \mathrm{~mm} /$ week), while P2 treatment was not significantly different $(0.35 \mathrm{~mm} /$ week) to control. At 22 weeks after planting (wap), root length and dry weight were not significantly different among treatments. While bark thickness in the control treatment was significantly higher than $P 1$ and $P 2$, the grafting successfulness percentage (GSP) was not significantly different among all treatments $(P O=63 \%, P 1=$ $56 \%$, and $P 2=74 \%)$. When referring to $26 \mathrm{~mm}$ maximum girth, the $P O$ could maintain the rootstock for only 17 months, while P1 up to 22 months and 19 months of P2. The two stages shoot pruning could extend rootstock lifetime up to 5 months and could be an alternative for producers to maintain the rootstock during low demand period.
\end{abstract}

Keywords: grafting successfulness; growth inhibition; Hevea brasiliensis; pruning; seedlings
Abstrak

Dalam kondisi permintaan bibit karet yang minim, upaya memperlambat pertumbuhan batang bawah diperlukan agar dapat digunakan dalam jangka waktu yang lebih lama. Penelitian ini bertujuan mengetahui pengaruh pemangkasan tajuk terhadap pertumbuhan batang bawah karet dalam polibeg. Penelitian disusun berdasarkan Rancangan Acak Kelompok (RAK) dengan tiga ulangan, setiap satuan percobaan terdiri dari 10 polibeg tanaman. Perlakuan pemangkasan tajuk terdiri dari tiga taraf yaitu PO (kontrol, tanpa pemangkasan), P1 (Pemangkasan dua tahap, di atas karangan daun pertama (6 minggu setelah tanam (mst)) dan di atas karangan daun kedua (9 mst), dan P2 (Pemangkasan satu tahap di atas karangan daun pertama $(6 \mathrm{mst}))$. Hasil pengamatan menunjukkan perlakuan P1 memiliki laju pertumbuhan diameter batang nyata lebih rendah $(0,30 \mathrm{~mm} / \mathrm{minggu})$ dibanding kontrol $(0,38 \mathrm{~mm} / \mathrm{minggu})$, sedangkan perlakuan P2 tidak berbeda nyata $(0,35$ $\mathrm{mm} /$ minggu) dibanding kontrol. Pada 22 mst, panjang dan bobot kering akar tidak berbeda nyata antar perlakuan. Ketebalan kulit pada perlakuan kontrol nyata lebih tinggi dibanding P1 dan P2 namun persentase keberhasilan okulasi tidak berbeda nyata antar perlakuan $(\mathrm{PO}=63 \%, \mathrm{P} 1$ $=56 \%$, dan $\mathrm{P} 2=74 \%$ ). Jika diameter batang bawah maksimal yang dianjurkan adalah 26 $\mathrm{mm}$, maka dengan perlakuan PO hanya dapat dipertahankan selama 17 bulan, sedangkan P1 selama 22 bulan dan P2 selama 19 bulan. Pemangkasan dua tahap dapat memperpanjang masa pakai batang bawah karet selama 5 bulan dibanding tanpa pemangkasan dan dapat menjadi 
alternatif bagi penangkar untuk menyiasati kondisi permintaan bibit yang minim.

Kata kunci: Batang bawah; Hevea brasiliensis; keberhasilan okulasi; pemangkasan; $\mathrm{p}$ e $\mathrm{n} \mathrm{g} \mathrm{h} \mathrm{a} \mathrm{m} \mathrm{b}$ a $\mathrm{t}$ a $\mathrm{n}$ pertumbuhan

\section{PENDAHULUAN}

Bibit karet (Hevea brasiliensis Muell. Arg.) diproduksi dengan perbanyakan vegetatif untuk mempertahankan kualitas genetik dari induknya. Beberapa metode perbanyakan vegetatif di antaranya stek (Masson et al., 2013), cangkok, dan kultur jaringan (Mignon et al., 2018) telah diuji coba, namun metode okulasi masih merupakan pilihan utama karena relatif mudah, murah, dan persentase keberhasilannya tinggi. Dalam pelaksanaan okulasi, dibutuhkan batang bawah (rootstock) dan mata tunas/batang atas (scion). Batang bawah selanjutnya akan menjadi pangkal batang dan sistem perakaran, sedangkan mata tunas akan menjadi tajuk meliputi batang, percabangan, dan daun. Bibit karet yang baik adalah kombinasi batang bawah yang memiliki kemampuan pembentukan perakaran yang baik dan batang atas yang memiliki potensi produksi tinggi dan tahan penyakit(Astuti et al., 2014).

Indonesia memiliki lebih dari 3 juta hektar tanaman karet (Direktorat Jenderal Perkebunan [Ditjenbun], 2016) sehingga kebutuhan bahan tanam karet, untuk peremajaan maupun pengembangan areal baru, sangat besar setiap tahunnya. Namun demikian, permintaan bibit karet untuk peremajaan maupun perluasan lahan berbanding lurus dengan harga karet. Pada saat harga karet tinggi, permintaan bibit meningkat karena antusiasme petani menanam karet. Sebaliknya ketika harga karet rendah, permintaan bibit karet menurun (Agustina et al., 2016). Saat permintaan tinggi penangkar berupaya meningkatkan pertumbuhan batang bawah agar segera dapat diokulasi dan dipasarkan. Upaya meningkatkan pertumbuhan batang bawah dapat dilakukan dengan modifikasi media tanam (Dharmakeerthi et al., 2012; Shara et al., 2014), pemupukan dan irigasi intensif (Nabayi et al., 2018). Bibit karet yang baik harus memenuhi standar mutu yang telah ditetapkan (Siagian, 2012b). Diameter maksimal bibit karet hasil okulasi berdasarkan Standar Nasional Indonesia (SNI) adalah $30 \mathrm{~mm}$ (Lasminingsih \& Oktavia, 2008), sedangkan menurut Siagian (2011) diameter batang bawah sebaiknya tidak lebih dari $26 \mathrm{~mm}$. Batang bawah yang terlanjur ditanam akan terus tumbuh, jika melewati ambang diameter yang distandarkan, bibit akan sulit dipasarkan. Dalam kondisi permintaan bibit yang minim, penangkar sering mengalami kerugian karena batang bawah yang sudah disiapkan tidak terpakai.

Upaya memperlambat pertumbuhan batang bawah diperlukan agar bibit dapat digunakan dalam jangka waktu yang lebih lama. Namun, studi untuk memperlambat pertumbuhan batang bawah masih jarang dilakukan. Penelitian Sarkar et al. (2015) menunjukkan bahwa aplikasi Paclobutrazol $\geq 100 \mathrm{mg} /$ tanaman dapat menghambat pertumbuhan lilit batang bibit karet hasil okulasi. Penelitian lainnya yang dilakukan oleh Admojo et al. (2018) menunjukkan bahwa perlakuan naungan (intensitas naungan 96\%) dan pemberian natrium klorida ( $\mathrm{NaCl})$ 0,5\% seminggu sekali selama tiga bulan juga dapat menghambat pertumbuhan batang bawah karet. Namun demikian, perlakuan-perlakuan tersebut kemungkinan sulit diadopsi karena membutuhkan biaya besar jika diaplikasikan dalam skala komersil, terutama untuk pembuatan naungan dan pembelian bahan kimia. Metode yang ideal bagi penangkar adalah yang cepat, mudah dan murah.

Pemangkasan tajuk tanaman sudah dikenal sejak lama sebagai salah satu metode rekayasa pertumbuhan tanaman. Pada seni bonsai misalnya, pemangkasan berkala yang dikombinasikan dengan perlakuan lainnya dapat menghasilkan tanaman kerdil yang bernilai estetika tinggi. Daun berperan penting bagi tanaman karena merupakan penghasil fotosintat yang menjadi bahan baku proses pertumbuhan dan perkembangan tanaman. Pemangkasan tajuk diduga dapat menekan pertumbuhan tanaman batang bawah karet akibat penurunan volume daun, sebagai penghasil asimilat, dan mendorong munculnya tunas 
baru yang membutuhkan asimilat. Hal ini menjadi dasar teori bahwa pemangkasan tajuk dapat menghambat pertumbuhan terutama lilit batang. Metode ini dipilih karena relatif mudah dan tidak membutuhkan biaya yang besar sehingga dinilai sesuai untuk penangkar bibit karet. Kombinasi pengendalian pertumbuhan batang bawah dan manajemen kebun entres dapat menjadi solusi untuk menjaga pasokan bibit karet sepanjang tahun.

\section{BAHAN DAN METODE}

Penelitian ini dilakukan di Balai Penelitian Sungei Putih, Galang, Deli Serdang, Sumatera Utara pada Oktober 2018 - Maret 2019. Lokasi penelitian berada pada ketinggian $\pm 54 \mathrm{~m}$ dpl (Akbar et al., 2013). Biji karet klon PB 260, salah satu klon yang direkomendasikan untuk batang bawah (Boerhendhy, 2009), dikumpulkan dari areal tanaman berumur 15 tahun di Kebun Percobaan Balai Penelitian Sungei Putih. Seleksi biji dilakukan secara visual dan uji lenting dengan cara dipantulkan pada permukaan ubin. Sebanyak 300 biji terpilih disemai dengan media pasir sungai di dalam rumah kaca. Selama persemaian penyiraman dilakukan setiap hari.

\section{Pembibitan Batang Bawah dan Perlakuan Pemangkasan}

Pembibitan batang bawah dilakukan dalam polibeg berukuran $40 \times 50 \mathrm{~cm}$ berisi top soil yang telah diayak. Polibeg ditempatkan di lapangan terbuka yang mendapat sinar matahari langsung dan disusun berdasarkan Rancangan Acak Kelompok (RAK) dengan tiga ulangan, setiap satuan percobaan terdiri dari 10 polibeg. Seleksi kecambah dilakukan dua minggu setelah semai kemudian dipindah ke polibeg secara manual. Selama pembibitan, kegiatan pemeliharaan dilakukan sesuai standar meliputi penyiraman setiap hari (kecuali hari hujan), pengendalian gulma manual seminggu sekali, dan pemupukan $\mathrm{N}$ P-K-Mg: 15-15-6-4 sebanyak 5 gram/polibeg dua minggu setelah tanam (mst). Pemangkasan tajuk dilakukan secara manual menggunakan pisau tajam, terdiri dari tiga taraf yaitu:

PO : Kontrol, tanpa pemangkasan.

P1 : Pemangkasan dua tahap. Pemangkasan pertama di atas karangan daun pertama (6 mst). Pemangkasan kedua di atas karangan daun kedua (9 mst).

P2 : Pemangkasan satu tahap di atas karangan daun pertama (6 mst).

\section{Pengamatan}

Pengamatan pertumbuhan tanaman dilakukan pada $5,10,14,18$, dan $22 \mathrm{mst}$ meliputi parameter tinggi tanaman, jumlah daun, dan diameter batang. Tinggi tanaman diamati dari pemukaan tanah dalam polibeg sampai titik tertinggi tanaman. Jumlah daun adalah jumlah daun yang telah terbentuk sempurna minimal pada fase B (Junaidi \& Atminingsih, 2017). Diameter batang diukur menggunakan jangka sorong digital pada ketinggian $5 \mathrm{~cm}$ dari permukaan tanah dalam polibeg. Laju pertambahan diameter batang (LPD) adalah diameter batang $(\mathrm{mm})$ dibagi umur tanaman (minggu).

Panjang akar, bobot akar, bobot tajuk, dan ketebalan kulit diamati pada satu tanaman pada setiap satuan percobaan yang dipilih secara acak setelah tanaman berumur 22 mst. Perakaran dicuci dengan air mengalir untuk memisahkan tanah yang melekat, selanjutnya panjang akar diukur dari pangkal batang. Sampel kulit diambil 5 $\mathrm{cm}$ dari pangkal batang dan diukur ketebalannya menggunakan jangka sorong digital. Akar dan tajuk dipisahkan pada pangkal batang selanjutnya bobot basah akar dan tajuk diukur menggunakan timbangan digital. Bobot kering diperoleh melalui pengeringan dalam oven dengan suhu $60^{\circ} \mathrm{C}$ selama 24 jam.

Okulasi dilakukan saat batang bawah berumur 22 mst menggunakan mata entres klon PB 260 yang diperoleh dari Kebun Percobaan Balai Penelitian Sungei Putih. Persentase keberhasilan okulasi (PKO) dihitung 3 minggu setelah okulasi dengan persamaan sebagai berikut: 
$P K O=\frac{J O H}{J T O} \times 100 \%$

Keterangan (Remarks):

PKO : Persentase keberhasilan okulasi (\%)

$\mathrm{JOH}$ : Jumlah okulasi hidup, ditandai dengan jendela okulasi berwarna hijau dan segar (tanaman)

JTO : Jumlah tanaman diokulasi (tanaman)

\section{Analisis Statistik}

Analisis data dilakukan menggunakan $R$ Statistic Software version 3.6.1 ( $R$ Development Core Team) dengan interface R Studio version 1.2.5001 (R Studio Inc.). Analysis of Variance (ANOVA) dilakukan untuk parameter laju pertambahan diameter batang, panjang akar, bobot kering akar, tebal kulit, dan persentase keberhasilan okulasi. Estimated Marginal Means dihitung menggunakan library (emmeans), sedangkan uji lanjut dilakukan menggunakan Tukey Family Comparison dengan $\alpha=0,05$.

\section{HASIL DAN PEMBAHASAN}

Parameter utama yang diamati dalam penelitian ini adalah diameter batang karena perlakuan ditujukan untuk menekan pertumbuhan lilit batang sehingga batang bawah dapat digunakan lebih lama. Selain itu, parameter penting lainnya adalah pertumbuhan akar karena fungsi batang bawah adalah menjadi sistem perakaran, dan keberhasilan okulasi yang menentukan jumlah bibit yang dapat dipasarkan. Oleh sebab itu, analisis data dan pembahasan difokuskan pada ketiga parameter tersebut, sedangkan parameter pertumbuhan lain meliputi tinggi tanaman, jumlah daun, dan bobot tajuk disajikan dalam Tabel lampiran.

\section{Diameter Batang}

Hasil pengamatan menunjukkan bahwa lilit batang sampai dengan $10 \mathrm{mst}$ relatif sama pada semua perlakuan $(\mathrm{PO}=$ $4,80 \mathrm{~mm}, \mathrm{P} 1=4,57 \mathrm{~mm}, \mathrm{P} 2=4,67 \mathrm{~mm}$ ). Setelah $10 \mathrm{mst}$ diameter batang antar perlakuan mulai menunjukkan perbedaan, pada 22 mst diameter batang PO mencapai $8,29 \mathrm{~mm}$, sedangkan P1 dan P2 masingmasing 6,56 $\mathrm{mm}$ dan 7,66 $\mathrm{mm}$ (Gambar 1A).
Hal ini menunjukkan bahwa laju pertambahan diameter batang (LPD) mengalami penurunan setelah pemangkasan. Perlakuan P1, dua kali pemangkasan, menunjukkan LPD nyata lebih rendah $(0,30 \mathrm{~mm} / \mathrm{minggu})$ dibanding kontrol $(0,38 \mathrm{~mm} / \mathrm{minggu})$, sedangkan perlakuan P2 (satu kali pemangkasan) tidak berbeda nyata $(0,35 \mathrm{~mm} / \mathrm{minggu})$ dibanding kontrol (Gambar 1B). Perlakuan dua kali pemangkasan dapat menurunkan LPD, sedangkan satu kali pemangkasan tidak berpengaruh signifikan terhadap diameter batang dibanding kontrol. Laju pertambahan lilit batang pada penelitian ini lebih rendah dibanding standar yaitu 0,5 $\mathrm{mm} / \mathrm{minggu}$ (Siagian, 2011) disebabkan pemupukan hanya dilakukan satu kali dengan dosis rendah (5 gram/polibeg). Pemupukan intensif merupakan salah satu cara yang efektif untuk meningkatkan LPD.

Diferensiasi sel kambium vaskular bertanggung jawab terhadap pertambahan diameter batang (Spicer \& Groover, 2010). Fotosintat dibutuhkan untuk pertumbuhan primer (primary growth) pada sel meristem apikal di ujung tunas dan akar maupun pertumbuhan sekunder (secondary growth) pada sel meristem lateral di kambium vaskular (Wang \& Ruan, 2016). Deslauriers et al. (2009) melaporkan bahwa pertumbuhan jaringan meristem batang berkaitan dengan ketersediaan carbon dalam zona kambium. Selain untuk pertumbuhan, fotosintat disimpan dalam bentuk cadangan karbohidrat digunakan untuk biosintesis partikel karet (Chantuma et al., 2009; Kanpanon et al., 2015). Penurunan volume tajuk melalui pemangksan menurunkan laju akumulasi asimilat dalam jaringan tanaman. Di samping itu, pemangkasan berperan dalam pematahan dominasi apikal dan mendorong pembentukan tunas baru. Pada perlakuan pemangkasan, laju pertambahan diameter batang lebih rendah dibanding tanpa pemangkasan karena sebagian cadangan karbohidrat digunakan untuk membentuk tunas baru. Kositsup et al. (2010) melaporkan bahwa laju asimilasi $\mathrm{CO}_{2}$ meningkat seiring umur daun dan mencapai maksimum sekitar umur 35 hari. Pada fase awal perkembangan, fase $\mathrm{A}$ dan $\mathrm{B}$, daun bersifat sink karena multiplikasi sel berlangsung sangat cepat untuk pembentukan aparatus fotosintesis, 
penambahan ukuran daun, dan peningkatan kadar klorofil. Pada fase ini energi diperoleh dari cadangan karbohidrat tanaman. Penelitian Miguel et al. (2007) menunjukkan fotosintesis bersih mulai positif pada fase C, sedangkan Lieberei (2007) dan Vinod et al. (2010) berpendapat bahwa daun bersifat source pada fase D. Pemangksan tajuk merubah keseimbangan source and sink tanaman melalui penunurunan total asimilat dan peningkatan penggunaan cadangan asimilat untuk pembentukan tunas baru. Keduanya berimplikasi terhadap menurunkan laju pertambahan diameter batang.

Mengacu pada Siagian (2011) dimana diameter batang bawah maksimal adalah 26 $\mathrm{mm}$, dengan rata-rata LPD sebagaimana

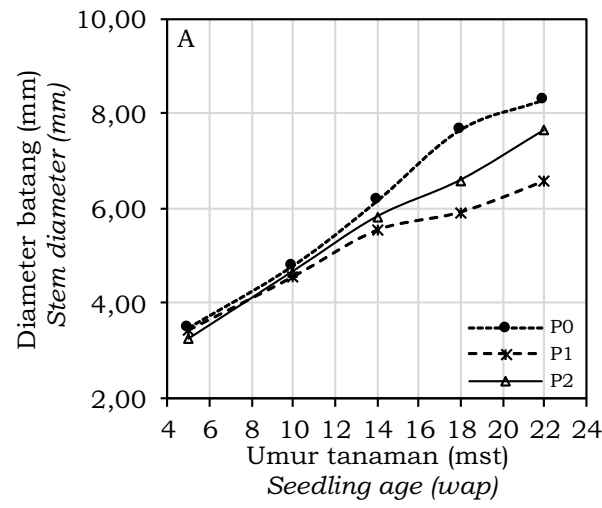

disajikan pada Gambar 1B, maka batang bawah dengan perlakuan PO hanya dapat dipertahankan selama 17 bulan, sedangkan P1 selama 22 bulan dan P2 selama 19 bulan. Hal ini menunjukkan bahwa dengan dua kali pemangkasan tajuk, masa pakai batang bawah dapat diperpanjang selama 5 bulan, sedangkan dengan satu kali pemangkasan masa pakai batang hanya dapat diperpanjang 2 bulan dibanding tanpa pemangkasan. Masa pakai batang bawah kemungkinan masih dapat diperpanjang dengan pemangkasan periodik dalam jangka panjang (lebih dari 2 kali pemangkasan) dan dikombinasikan dengan modifikasi faktor lain seperti air dan unsur hara. Namun hal ini masih perlu dibuktikan dengan penelitian lebih lanjut.

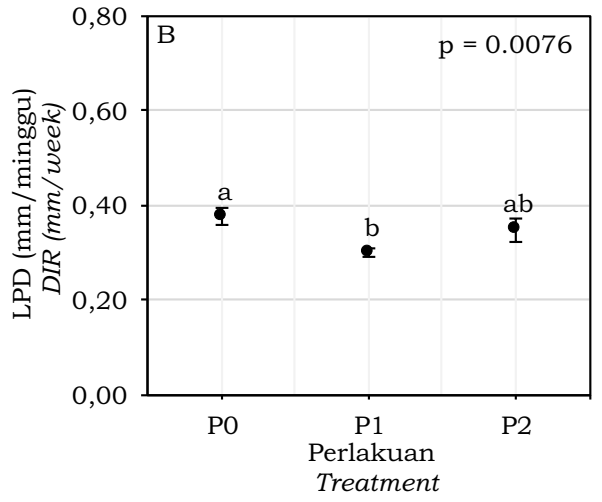

Gambar 1. Tinggi tanaman pada 22 MST (A) dan rata-rata laju pertambahan diameter batang (B). Error bar menunjukkan standar deviasi. Huruf yang berbeda antar perlakuan menunjukkan berbeda nyata pada $\alpha=0,05$ berdasarkan Tukey Comparison Method

Figure 1. Seedlings diameter at 22 WAP (A) and stem diameter increment rate (B). Error bar indicated standard deviation. Different letter among treatment indicated a significant difference at $\alpha=0.05$ based on Tukey Comparison Method

\section{Pertumbuhan Akar}

Sistem perakaran sangat penting bagi tanaman untuk menopang tajuk, penyerapan unsur hara, dan adaptasi terhadap cekaman abiotik seperti kekeringan (Feng et al., 2011) dan cekaman biotik contohnya penyakit akar (Wattanasilakorn et al., 2012 ; Wattanasilakorn et al., 2017). Penelitian terdahulu menunjukkan bahwa interaksi batang bawah (rootstock) dan batang atas (scion) menentukan pertumbuhan dan produksi karet (Nascimento et al., 2011; Yuan et al., 2011). Pada tanaman karet, batang bawah yang direkomendasikan adalah yang berasal dari biji klon GT 1, AVROS 2037, BPM 24, PB 260, dan RRIC 100 (Boerhendhy, 2009). Pada penelitian ini, terdapat kecenderungan bahwa pemangkasan tajuk mendorong pemanjangan akar namun menurunkan bobot akar (Gambar 2), namun hasil analisis statistik menunjukkan bahwa panjang (Gambar 3A) dan bobot kering akar (Gambar 3B) tidak berbeda nyata antar perlakuan. Pada 22 mst, akar terpanjang P0 adalah $28,83 \mathrm{~cm}$, P1 36,67 cm dan P2 $30 \mathrm{~cm}$ sedangkan bobot akar masing-masing P0 7,94 g, P1 4,58 g dan P2 7,22 g. 


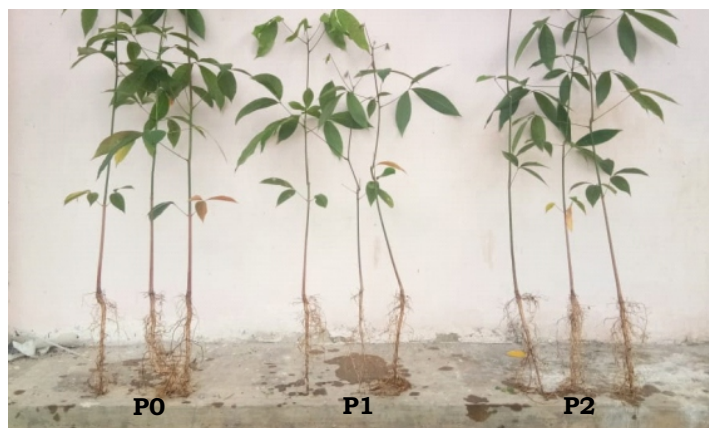

Gambar 2. Akar tanaman sampel berumur 22 MST

Figure 2. Roots of sample plants at 22 at 22 WAP

Thaler dan Pages (1996a, 1996b) melaporkan bahwa pertumbuhan akar tanaman karet berlangsung secara ritmik dipengaruhi oleh ketersediaan fotosintat. Sedangkan penelitian Maeght et al. (2015) menunjukkan peran kadar air tanah terhadap variasi musiman pertumbuhan akar tanaman karet. Hasil pengamatan pertumbuhan akar pada penelitian ini berbeda dengan Saifuddin et al. (2010) yang melaporkan bahwa pemangkasan menurunkan panjang dan bobot akar secara siginifikan. Penelitian sejenis pada Quercus pubescens (Willaume \& Pages, 2011) dan Acacia saligna (Peter \& Lehmann, 2000) menunjukkan bahwa ketersediaan karbohidrat berkorelasi positif terhadap pertambahan panjang dan diameter akar. Pada penelitian ini, pemangkasan tajuk yang dilakukan di atas karangan daun menyisakan daun dewasa yang memiliki fotosintesis bersih positif Miguel et al. (2007) sehingga akar tetap tumbuh. Selain itu selain itu, penyiraman dilakukan setiap hari

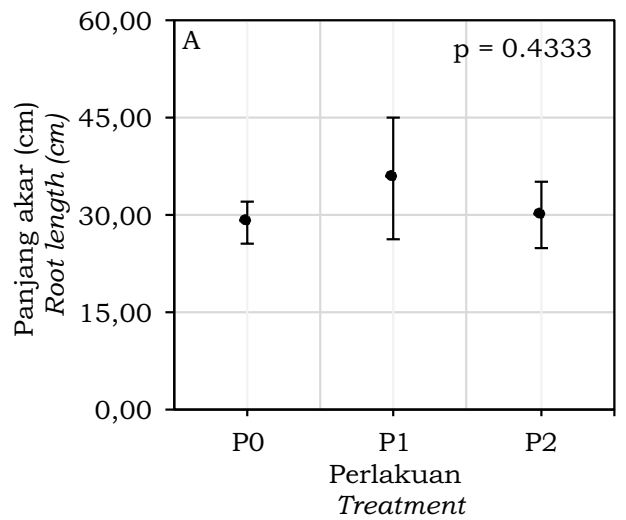

sehingga relatif tidak ada fluktuasi kadar air tanah yang signifikan. Hal ini diduga menjadi penyebab panjang akar dan bobot akar pada perlakuan pemangkasan tidak berbeda nyata dibanding kontrol.

Berbeda dengan stum okulasi mata tidur (SOMT) yang dipotong perakarannya sebelum ditanam ke polibeg, pembibitan langsung dalam polibeg memiliki perakaran lebih baik karena tidak terganggu sampai bibit ditanam di lapangan, (Siagian \& Bukit, 2015). Pada penelitian ini, masa pakai yang lebih lama memberi kesempatan tanaman membentuk tajuk dan meningkatkan biomassa akar pada perlakuan pemangkasan terutama P1. Yao et al. (2017) melaporkan bahwa batang bawah klonal (dari somatic embryogenesis) dan dari biji tidak menunjukkan pertumbuhan yang berbeda secara signifikan. Hal ini mengindikasikan bahwa biji masih akan digunakan sebagai sumber batang bawah karet.

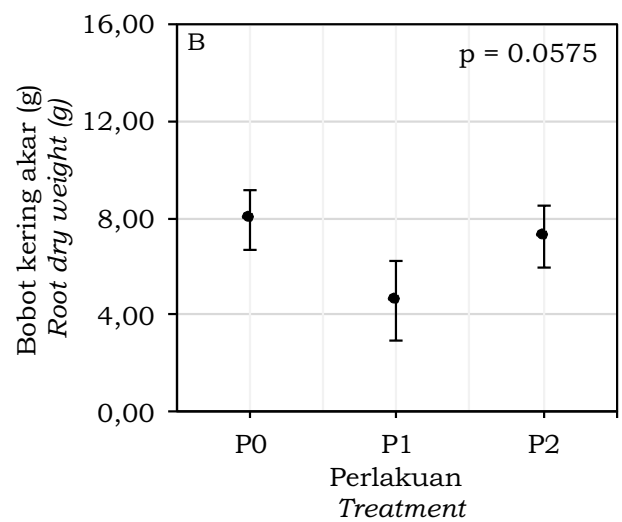

Gambar 3. Panjang akar (A) dan bobot kering akar (B) pada 22 MST. Error bar menunjukkan standar deviasi

Figure 3. Root length (A) and root dry weight (B) at 22 WAP. Error bar indicated standard deviation 


\section{Keberhasilan Okulasi}

Untuk mendapatkan bibit karet yang bermutu, batang bawah diokulasi dengan mata entres dari klon anjuran. Tingkat keberhasilan okulasi sangat menentukan jumlah bibit yang dapat dipasarkan. Secara umum, keberhasilan teknik okulasi dipengaruhi oleh waktu pelaksanaan okulasi (musim), kompatibilitas batang atas dan batang bawah, umur jaringan tanaman, suhu, orientasi batang atas, pemeliharaan setelah okulasi, kelembaban tanah, dan kontak antara batang atas dan batang bawah (Kumar, 2011). Khusus untuk tanaman karet, Hadi (2010) menyatakan bahwa ketebalan kulit batang bawah menentukan tingkat keberhasilan okulasi. Pada penelitian ini, ketebalan kulit pada perlakuan kontrol nyata lebih tinggi $(0,71$ $\mathrm{mm})$ dibanding $\mathrm{PO}(0,46 \mathrm{~mm})$ dan $\mathrm{P} 1(0,53$ $\mathrm{mm}$ ) (Gambar 4A) namun persentase keberhasilan okulasi (PKO) tidak berbeda nyata antar perlakuan masing-masing $63 \%$ pada perlakuan P0, 56\% pada perlakuan $\mathrm{P} 1$ dan $74 \%$ pada perlakuan P2 (Gambar 4B). Hal ini menunjukkan bahwa keberhasilan okulasi pada tanaman karet tidak hanya ditentukan oleh ketebalan kulit, melainkan banyak faktor yang saling berinteraksi.

Berdasarkan hasil penelitian terdahulu, beberapa faktor yang

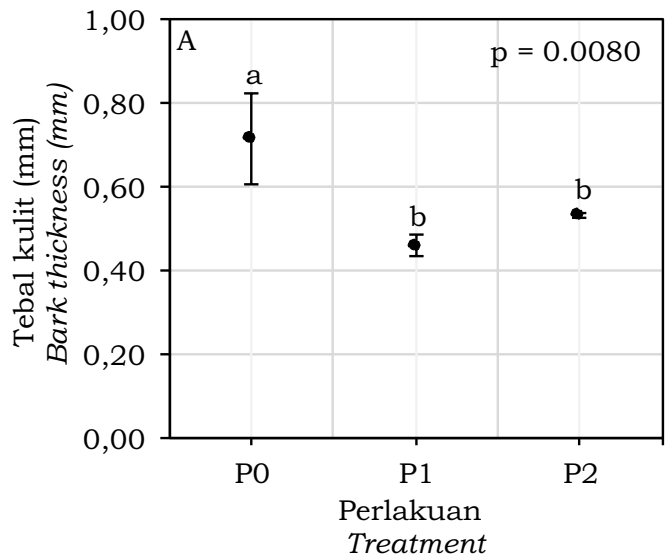

mempengaruhi keberhasilan okulasi tanaman karet antara lain umur batang bawah (Heryana et al., 2014), media tanam (Yustisia, 2017), waktu pelaksanaan okulasi (Pudjiono \& Adinugraha, 2013), dan jenis mata entres (Udayakumara \& Seneviratne, 2005; Junaidi et al., 2014). Keberhasilan okulasi juga dipengaruhi aktivitas kambium, Sariningtias et al. (2014) menyatakan bahwa keberhasilan okulasi tinggi jika dilakukan pada periode sel kambium aktif membelah. Periode ini ditandai dengan kulit batang bawah maupun batang atas mudah dikelupas dari kayunya. Marcati et al. (2016) dan Rahman et al. (2019) melaporkan bahwa pada saat kadar air tanah tinggi (musim hujan) kambium aktif sedangkan pada musim kemarau kambium dorman. Hal ini sejalan dengan hasil penelitian Omokhafe et al. (2016) yang menunjukkan bahwa curah hujan dan kelembaban udara pada pagi dan sore hari berkorelasi positif terhadap keberhasilan okulasi, sedangkan temperatur maksimum dan minimum, evaporasi, dan tingkat radiasi berkorelasi negatif. Pada penelitian ini, persentase keberhasilan okulasi antara kontrol dan perlakuan pemangkasan tidak berbeda nyata diduga karena kadar air tanah relatif stabil akibat penyiraman yang dilakukan setiap hari.

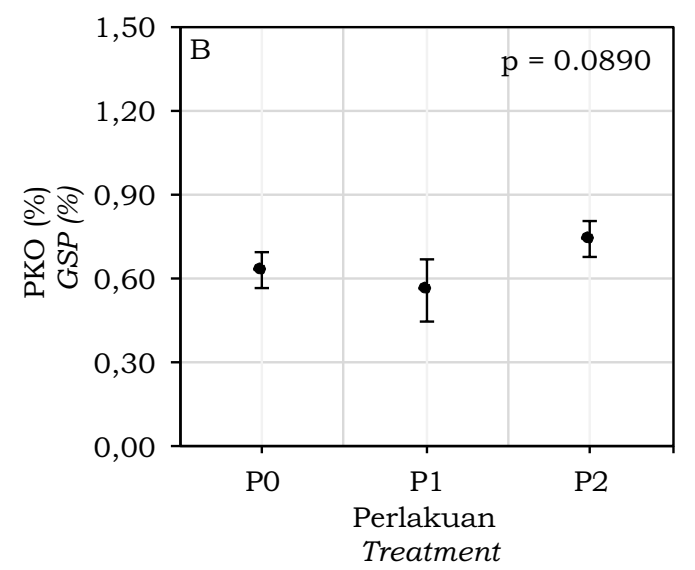

Gambar 4. Tebal kulit (A) pada minggu ke-22 dan persentase keberhasilan okulasi (B). Error bar menunjukkan standar deviasi. Huruf yang berbeda antar perlakuan menunjukkan berbeda nyata pada $\mathrm{a}=0.05$ berdasarkan Tukey Comparison Method.

Figure 4. Bark thickness at 22 WAP (A) and grafting successfulness percentage (GSP) (B). Error bar indicated standard deviation. Different letter among treatment indicated a significant difference at $\alpha=0.05$ based on Tukey Comparison Method. 
Tujuan pembibitan karet adalah menghasilkan bibit okulasi. Berdasarkan umur batang bawah yang digunakan, okulasi dapat dibedakan menjadi okulasi coklat (umur batang bawah $7-12$ bulan), okulasi hijau ( $4-7$ bulan) dan okulasi dini ( 2 - 4 bulan) (Junaidi et al., 2014). Okulasi coklat dan okulasi hijau telah umum dilakukan, sedangkan okulasi dini masih dipraktekkan dalam skala terbatas (Boerhendhy, 2014). Penelitian ini menggunakan teknik okulasi hijau dalam polibeg. Bibit hasil okulasi dari perlakuan pemangkasan tajuk (P1 dan P2) maupun kontrol (P0) menunjukkan kualitas fisik yang baik (Gambar 5). Namun di lapangan, sebagian besar penangkar menggunakan teknik okulasi coklat dengan batang bawah ditanam di lapangan kemudian dipanen dalam bentuk stum okulasi mata tidur (SOMT). Karakteristik perakaran di pembibitan lapangan kemungkinan berbeda dengan di polibeg. Oleh sebab itu, penelitian sejenis perlu dilakukan untuk mengetahui respon tanaman terhadap pemangkasan.

Ketersediaan batang bawah merupakan salah satu titik kritis dalam penyediaan bibit karet selain ketersediaan biji dan mata entres. Pembungaan dan pembentukan biji tanaman karet dipengaruhi oleh intensitas radiasi matahari sehingga musim biji berbeda-beda di setiap wilayah (Yeang, 2007). Hal ini menguntungkan bagi Indonesia yang terletak di khatulistiwa, sebagian sentra tanaman karet berada di belahan bumi utara dan sebagian di belahan selatan sehingga biji relatif tersedia sepanjang tahun dari lokasi yang berbeda. Ketersediaan mata entres dapat dikendalikan dengan pengelolaan kebun entres yang baik (Siagian, 2012a). Kombinasi ketiga faktor tersebut dapat menjamin ketersediaan bibit karet sepanjang tahun.

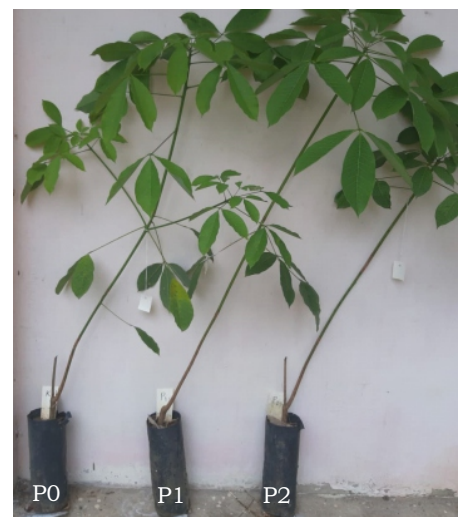

Gambar 5 . Bibit hasil okulasi berumur 8 bulan setelah okulasi Figure 5. Budded planting materials at 8 months after budding

\section{KESIMPULAN}

Pemangkasan dua tahap dapat menurunkan laju pertambahan diameter batang bawah di polibeg, sedangkan satu kali pemangkasan tidak berpengaruh signifikan terhadap diameter batang. Panjang dan bobot kering akar tidak berbeda nyata antar perlakuan. Ketebalan kulit pada perlakuan pemangkasan lebih rendah dibanding tanpa pemangkasan namun tidak mempengaruhi tingkat keberhasilan okulasi. Berdasarkan hasil penelitian ini, pemangkasan dua tahap dapat memperpanjang masa pakai batang bawah karet selama 5 bulan dibanding tanpa pemangkasan. Cara ini bermanfaat bagi penangkar untuk menyiasati kondisi permintaan bibit yang minim. 


\section{DAFTAR PUSTAKA}

Admojo, L., Nugrahani, M. O., \& Prasetyo, N. E. (2018). Perlakuan naungan dan pemberian $\mathrm{NaCl}$ untuk menghambat pertumbuhan batang bawah karet (Hevea brasiliensis Muell. Arg.). Jurnal Penelitian Karet, 36(1), 25-36. Doi: 10.22302.ppk.jpk.v36i1.439

Agustina, D. S., Syarifa, L. F., \& Nancy, C. (2016). Kajian prospek bisnis pembibitan karet di Provinsi Sumatera Selatan. Jurnal Penelitian Karet, 34(2), 225-236. Doi: 10.22302.jpk.v34i2.227

Akbar, T., Kardhinata, E. H., Bayu, E. S., \& Woelan, S. (2013). Seleksi projeni tanaman karet (Hevea brasiliensis) dari hasil persilangan tahun 2001-2003 sebagai penghasil lateks kayu. Jurnal Online Agroekoteknologi, 1(3), 655-667.

Astuti, M., Hafiza, Yuningsih, E., Wasingun, A. R., Nasution, I. M., \& Mustikawati, D. (2014). Pedoman Budidaya Karet (Hevea brasiliensis) yang Baik. Jakarta: Indonesia Direktorat Jenderal Perkebunan, Kementerian Pertanian.

Boerhendhy, I. (2009). Penglolaan biji karet untuk bibit. Warta Penelitian dan Pengembahan Pertanian, 31(5), 6-9.

Boerhendhy, I. (2014). Prospek perbanyakan bibit karet unggul dengan teknik okulasi dini. Jurnal Penelitian dan Pengembangan Pertanian, 32(2), 85-90.

Chantuma, P., Lacointe, A., Kasemsap, P., Thanisawanyangkura, S., Guilliot, A., Ame, T., \& Ame, T. (2009). Carbohydrate storage in wood and bark of rubber trees submitted to different level of $\mathrm{C}$ demand induced by latex tapping. Tree Physiology, 29, $1021-1031$. Doi: 10.1093 . treephys.tpp043

Deslauriers, A., Giovannelli, A., Rossi, S., Castro, G., Fragnelli, G., \& Traversi, L. (2009). Intra-annual cambial activity and carbon availability in stem of poplar. Tree Physiology, 29, 1223-1235. Doi: 10.1093.treephys.tpp061
Dharmakeerthi, R. S., Chandrasiri, J. A. S., \& Edirimanne, V. U. (2012). Effect of rubber wood biochar on nutrition and growth of nursery plants of Hevea brasiliensis established in an Ultisol. SpringerPlus, 1(1), 84. Doi: 10.1186. 2193-1801-1-84

Direktorat Jenderal Perkebunan. (2016). Statistik Perkebunan Indonesia 2015 . 2017: Karet. Jakarta, Indonesia: Ditjenbun

Feng, A., Lingxue, K., Lidan, G., Zhenhui, W., $\&$ Weifu, L. (2011). Involvement of rootstocks and their hydraulic conductance in the drought resistance of grafted rubber trees. African Journal of Biotechnology, 10(51), 10393-10404. Doi: 10.589.AJB11.354

Hadi, R. (2010). Teknik dan tingkat keberhasilan okulasi beberapa klon karet anjuran di kebun visitor plot BPTP Jambi. Buletin Teknik Pertanian, 15(1), 39-42.

Heryana, N., Saefudin, S., \& Sobari, I. (2014). Pengaruh umur batang bawah terhadap persentase keberhasilan okulasi hijau pada tiga klon karet (Hevea brasiliensis Muell Agr.). Jurnal Tanaman Industri dan Penyegar, 1(2), 95. Doi: 10.21082.jtidp.v1n2.2014. p95-100

Junaidi, Atminingsih, \& Siagian, N. (2014). Pengaruh jenis mata entres dan klon terhadap keberhasilan okulasi dan pertumbuhan tunas pada okulasi hijau di polibeg. Jurnal Penelitian Karet, $32(1), 21-30$. Doi: 10.22302 .jpk.v32i1.146

Junaidi, \& Atminingsih, A. (2017). Perkembangan ontogenetik daun tanaman karet sebagai penanda awal adaptasi terhadap cekaman lingkungan dan patogen. Warta Perkaretan, 36(1), 29-38. Doi: 10.22302.ppk.wp. v36i1.296 
Kanpanon, N., Kasemsap, P., Thaler, P., Kositsup, B., Gay, F., Lacote, R., \& Epron, D. (2015). Carbon isotope composition of latex does not reflect temporal variations of photosynthetic carbon isotope discrimination in rubber trees (Hevea brasiliensis). Tree Physiology, 35, 1166-1175. Doi: 10.1093.treephys.tpv070

Ko sitsup, B., Ka s e m sa p, P., Thanisawanyangkura, S., Chairungsee, N., Satakhun, D., Teerawatanasuk, K., \& Thaler, P. (2010). Effect of leaf age and position on light-saturated $\mathrm{CO}_{2}$ assimilation rate, photosynthetic capacity, and stomatal conductance in rubber trees. Photosynthetica, 48(1), 67-78. Doi: 10.1007.s11099-0100010-y

Kumar, G. N. M. (2011). Propagation of Plants by Grafting and Budding. A Pacific Northwest Extension Publication, PNW496.

Lasminingsih, M., \& Oktavia, F. (2008). Mutu bahan tanam karet dan sosialisasi SNIRSNI bibit karet. Warta Perkaretan, 27(1), 35-49.

Lieberei, R. (2007). South American Leaf Blight of the rubber tree (Hevea spp.): new steps in plant domestication using physiological features and molecular markers. Annals of Botany, 100(6), 1125-1142. Doi: 10.1093/aob/ $\mathrm{mcm} 133$

Maeght, J., Gonkhamdee, S., Clément, C., Ayutthaya, S. I. N., Stokes, A., \& Pierret, A. (2015). Seasonal patterns of fine root production and turnover in a mature rubber tree (Hevea brasiliensis Müll. Arg.) stand-differentiation with soil depth and implications for soil carbon stocks. Frontier in Plant Science, 6(November), 1-11. Doi: 10.3389.fpls. 2015.01022

Marcati, C. R., Machado, S. R., Sotto, D., Totti, N. O., Lara, D., Bosio, F., \& Wiedenhoeft, A. C. (2016). Cambial activity in dry and rainy season on branches from woody species growing in Brazilian Cerrado. Flora, 223, 1-10. Doi: 10.1016.j.flora.2016.04.008
Masson, A., Julien, J.-M., \& Boedt, L. (2013). Mass production by rooted cuttings of mature selected clones of Hevea brasiliensis. Bois et Foret Des Tropique, 317(3), 51-58.

Mignon, E., \& Werbrouck, S. (2018). Somatic embryogenesis as key technology for shaping the rubber tree of the future. Frontiers in Plant Science, 9(December), 1-6. Doi: 10.3389.fpls.2018.01804

Miguel, A. A., Oliveira, L. E. M. de, Cairo, P. A. R., \& Oliveira, D. M. de. (2007). Photosynthetic behaviour during the leaf ontogeny of rubber tree clones [Hevea brasiliensis (Wild. ex. Adr. de Juss.) Muell. Arg.], in Lavras, MG. Ciência e Agrotecnologia, 31(1), 91-97. Doi: $10.1590 . \mathrm{S} 1413-70542$ 007000100014

Nabayi, A., Teh, C. B. S., Husni, M. H. A., \& Sulaiman, Z. (2018). Plant growth, nutrient content and water use of rubber (Hevea brasiliensis) seedling grown using root trainer and different irrigation systems. Pertanika Journal of Tropical Agricultural Science, 41(1), 251-270.

Nascimento, E. S. P. do, Oliveira, C. R. de, Gonçalves, P. de S., Costa, R. B. da, Moreno, R. M. B., Mattoso, L. H. C., \& Ferreira, A. G. (2011). Effect of rootstock on the scion of Hevea brasiliensis through metabolic analysis of latex samples by ${ }^{1} \mathrm{H}$ NMR. Crop Breeding and Applied Biotechnology, S1, 82-88. Doi: 10.1590.S1984-70332011000500012

Omokhafe, K. O., Emuedo, O. A., \& Imoren, E. A. (2016). Intercharacter correlation between budding success in Hevea brasiliensis Muell. Arg. and seven weather characters. International Journal of Plant \& Soil Sciende, 11(4), 1-5. Doi: 10.9734.IJPSS.2016/26227

Peter, I., \& Lehmann, J. (2000). Pruning effects on root distribution and nutrient dynamics in an acacia hedgerow planting in northern Kenya. Agroforestry Systems, 50, 59-75. 
Pudjiono, S., \& Adinugraha, H. A. (2013). Pengaruh klon dan waktu okulasi terhadap pertumbuhan dan persentase hidup okulasi jati (Tectona grandis). Wana Benih, 14(3), 103-108.

Rahman, H., Nugroho, W. D., Nakaba, S., Kitin, P., Kudo, K., Yamagishi, Y., \& Begum, S. (2019). Changes in cambial activity are related to precipitation patterns in four tropical hardwood species grown in Indonesia. American Journal of Botany, 106(6), 760-771. Doi: 10.1002.ajb2.1297

Saifuddin, M., Hossain, A. B. M. S., Osman, N., Sattar, M. A., Moneruzzaman, K. M., \& Jahirul, M. I. (2010). Pruning impacts on root-shoot-growth, biochemical and physiological changes of Bougainvillea glabra. Australian Journal of Crop Science, 4(7), 530-537.

Sariningtias, N. W., Poerwanto, R., \& Gunawan, E. (2014). Penggunaan Benzil Amino Purin (BAP) pada okulasi jeruk keprok (Citrus reticulata). Jurnal Hortukultura Indonesia, 5(3), 158-167.

Sarkar, J., Annamalainathan, K., Krishnakumar, R., \& Jacob, J. (2015). Morphological changes in young plants of Hevea brasiliensis induced by paclobutrazol. Rubber Science, 28(1), 22-30.

Shara, D., Izzati, M., \& Prihastanti, E. (2014). Perkecambahan biji dan pertumbuhan bibit batang bawah karet (Havea brasiliensis Muell Arg.) dari klon dan media yang berbeda. Jurnal Biologi, 3(3), 60-74.

Siagian, N. (2011). Seleksi dan standar mutu bibit karet unggul. Workshop Penggunaan Klon Unggul Baru dan Sistem Eksploitasi Tanaman Karet yang Tepat Dalam Menghadapi Peningkatan Harga Karet Alam Dunia, 1-17. Medan: Balai Penelitian Sungei Putih, Pusat Penelitian Karet.

Siagian, N. (2012a). Juvenilitas sumber mata okulasi dan pengelolaan entres. Warta Perkaretan, 31(2), 57-65. Doi: 10.22302.ppk.wp.v31i2.267
Siagian, N. (2012b). Pembibitan dan Pengadaan Bahan Tanam Karet Unggul. Medan, Indonesia: Balai Penelitian Sungei Putih, Pusat Penelitian Karet.

Siagian, N., \& Bukit, E. (2015). Komparasi teknis dan finansial pengadaan benih melalui okulasi tanaman di polibeg dengan okulasi di lapangan. Warta Perkaretan, 34(2), 115-126. Doi: 10.22302.ppk.wp.v34i2.253

Spicer, R., \& Groover, A. (2010). Evolution of development of vascular cambia and secondary growth. New Phytologist, 186(3), 577-592. Doi: 10.1111.j.14698137.2010.03236.x

Thaler, P., \& Pages, L. (1996a). Periodicity in the development of the root system of young rubber trees (Hevea brasiliensis Muell. Arg.): relationship with shoot development. Plant, Cell and Environment, 19(1), 56-64. Doi: 10.1111/j.1365-3040.1996.tb00226.x

Thaler, P., \& Pages, L. (1996b). Root apical diameter and root elongation rate of rubber seedlings (Hevea brasiliensis) show parallel responses to photoassimilate availability. Physiologia Plantarum, 97(2), 365-371. Doi: $10.1034 / j .1399-3054.1996$. 970222.x

Udayakumara, E. P. N., \& Seneviratne, P. (2005). Position of the bud on the bud stick on success of bud graft and growth Hevea brasiliensis (Muell Arg). The Journal of Agricultural Science, 1(1), 31-40.

Vinod, K. K., Rajeswari Meenattoor, J., Nanja Reddy, Y. A., Priyadarshan, P. M., Chaudhuri Vinod, D. K., Meenattoor, R. J., \& Chaudhuri, D. (2010). Ontogenetic variations in flush development are indicative of low temperature tolerance in Hevea brasiliensis clones. Annals of Forest Research, 53(2), 95-105.

Wang, L., \& Ruan, Y.-L. (2016). Shoot-root carbon allocation, sugar signalling and their coupling with nitrogen uptake and assimilation. Functional Plant Biology, 43(2), 105. Doi: 10.1071.FP15249 
Wattanasilakorn, S., Sdoodee, S., Nualsri, C., \& Chuenchit, S. (2012). Screening of rubber (Hevea brasiliensis Muell. Arg.) rootstocks for the white root disease resistance. Journal of Agricultural Technology, 8(7), 2385-2395.

Wattanasilakorn, S., Sdoodee, S., Nualsri, C., Chuenchit, S., Meesawat, U., \& Sopharat, J. (2017). Assessment of rubber clonal rootstocks for the tolerance of white root disease (Rigidoporus microporus) in Southern Thailand. Walailak Journal of Science and Technology, 14(7), 549-561. Doi: 10.14456.vol14iss9pp

Willaume, M., \& Pages, L. (2011). Correlated responses of root growth and sugar concentrations to various defoliation treatments and rhythmic shoot growth in oak tree seedlings (Quercus pubescens). Annals of Botany, 107, 653-662. Doi: 10.1093.aob.mcq270

Yao, X., Chen, X., Wang, J., Zhou, J., Cai, M., $\&$ Lin, W. (2017). Effect of clonal rootstocks on the growth and yield of Hevea rubber. Journal of Rubber Research, 20(3), 203-212. Doi: 10.1007.BF03449152
Yeang, H. Y. (2007). Synchronous flowering of the rubber tree (Hevea brasiliensis) induced by high solar radiation intensity. New Phytologist, 175(2), 283-289. Doi: 10.1111.j.14698137.2007.02089.x

Yuan, K., Ding, X., Yang, L. F., Wang, Z. H., Lin, W. F., \& Cao, J. H. (2011). Proteome analysis of interaction between rootstocks and scions in Hevea brasiliensis. African Journal of Biotechnology, 10(66), 14816-14825. Doi: 10.5897.AJB11.1844

Yustisia, D. (2017). Tingkat keberhasilan okulasi pada berbagai klon dan komposisi media tanam terhadap pertumbuhan tanaman karet (Hevea brasiliensis Muell. Arg.). Agrominansia, 3(2), 110-118. Doi: 10.34003/271977 